\title{
Enzyme replacement therapy and fatigue in adults with Pompe disease
}

\author{
Deniz Güngör ${ }^{*}$, Juna de Vries, Esther Brusse, Michelle Kruijshaar, Linda van den Berg, Wim Hop, Arnold Reuser, \\ Pieter van Doorn, Marloes Hagemans, Iris Plug, Ans van der Ploeg
}

From Proceedings of the 6th European Symposium: Steps Forward in Pompe Disease Berlin, Germany. 23-24 November 2012

\section{Introduction}

Fatigue is a common and often disabling symptom among both mildly and severely affected adult patients with Pompe disease. Our objective was to determine whether enzyme replacement therapy (ERT) reduces fatigue in adult patients with Pompe disease.

\section{Methods}

Data was collected as part of an international longitudinal survey ('IPA/ Erasmus MC Pompe Survey'). Fatigue was measured with the Fatigue Severity Scale (FSS). Repeated measurements ANOVA were used to analyze the data over time. We also evaluated muscle strength using the Medical Research Council (MRC) scale, measured pulmonary function as Forced Vital Capacity (FVC), and assessed depression using the Hospital Anxiety and Depression scale (HADS).

\section{Results}

We followed 163 patients for a median of 4 years before ERT and for 3 years during ERT. At start of ERT, 68\% of patients were severely fatigued (FSS $\geq 5$ ), against $55 \%$ at their last follow-up. During ERT, mean FSS scores declined significantly $(-0.13$ score points per year; $\mathrm{p}<0.001)$ - a significant improvement on the period before treatment (difference -0.14 FSS score-points per year, $\mathrm{p}<0.01$ ). Patients' improvements in fatigue were correlated with their response to ERT in muscle strength (correlation coefficient: -0.55) and depression (correlation coefficient: 0.34), but not with the effect of ERT on pulmonary function.

Departments of Pediatrics, Neurology and Clinical Genetics, Center for Lysosomal and Metabolic Diseases, Erasmus MC University Medical Center, Rotterdam, The Netherlands

\section{Conclusion}

Fatigue is a prominent symptom in adult Pompe disease. Although it decreased during ERT, over half of the patients remained severely fatigued after a median of 3 years of therapy. To manage fatigue optimally in these patients, ERT should therefore be combined with other strategies that target fatigue. Further investigation is needed into the exact role of muscle strength, depression and other factors that may be associated with fatigue.

Published: 29 May 2013

doi:10.1186/1471-2474-14-S2-P16

Cite this article as: Güngör et al.: Enzyme replacement therapy and

fatigue in adults with Pompe disease. BMC Musculoskeletal Disorders 2013 14(Suppl 2):P16.
Submit your next manuscript to BioMed Central and take full advantage of:

- Convenient online submission

- Thorough peer review

- No space constraints or color figure charges

- Immediate publication on acceptance

- Inclusion in PubMed, CAS, Scopus and Google Scholar

- Research which is freely available for redistribution

Submit your manuscript at www.biomedcentral.com/submit

\section{() Biomed Central}

